\title{
This Vast Southern Empire: Slaveholders at the Helm of American Foreign Policy
}

Review Number: 2106

Publish date: Thursday, 11 May, 2017

Author: Matthew Karp

ISBN: 9780674737259

Date of Publication: 2016

Price: $£ 23.95$

Pages: 368pp.

Publisher: Harvard University Press

Publisher url: http://www.hup.harvard.edu/catalog.php?isbn=9780674737259

Place of Publication: Cambridge, MA

Reviewer: David Tiedemann

Matthew Karp's This Vast Southern Empire: Slaveholders at the Helm of American Foreign Policy seeks to explain the worldview of elite Southern slave-owners in the antebellum era. Karp does not simply present the way these slaveholders thought about issues like the Atlantic struggle over abolition, manumission in other slave societies, or American filibustering, but also how these global events influenced federal policy. The book is lucidly written and the argument covers a lot of ground easily, engaging with Southern military, congressional, diplomatic, and intellectual history. Much of the book deals with the nexus between the development and contours of the slaveholding worldview and federal military and foreign policy. This Vast Southern Empire gels well with recent studies that seek to place slavery in a larger global context. Comparison to Sven Beckert's Empire of Cotton (1) is clear, but the book also fits with older scholarship. Karp's examination of the slaveholding worldview places bondage in the same milieu of industry and investment as Hobsbawm's The Age of Capital.(2) This Vast Southern Empire is an excellent synthesis dealing with the beliefs of elite slaveholders, their influence on American foreign policy, and the position of bondage as a part of 19th-century capitalism. Also, though I have no idea whether Karp had any influence on this or not, but This Vast Southern Empire has a very fetching cover.

The start of This Vast Southern Empire presents slave-owners as people with a singular belief in slavery held above all other political views. Slaveholders were not, for Karp, believers principally in states' rights or Jeffersonian small government but were willing to employ any idea or argument to justify the institution they economically depended on. Karp illustrates this point with the anecdote that the first recorded mentions of Hegel and Comte in Congress were to buttress pro-slavery arguments. Elite Southern slaveholders were willing to cast their net in any direction to find an argument to buttress the institution, even to contemporary continental philosophy. However, rather than suggesting that these Southerners simply believed in slavery and nothing else, Karp makes a much more specific argument. This Vast Southern Empire contrasts two specific elements of the slaveholding worldview. First, that American slaveholders thought about their economic model in global rather than strictly national terms. Slaveholders believed the institution should be supported and defended wherever it existed. Second, that elite Southerners cast slavery as a modern tool to exploit regions of the world, that to exploit certain areas like the Caribbean to their full capacity in the capitalist world required slave labour. Juxtaposing these concepts leads to the conclusion that states' rights 
was a mere opportunistic rhetorical device for Southern politicians in the antebellum era, and that slaveholders grappled with Northerners for mastery of the federal government as a tool to defend slaveowning interests. Slaveholders' global vision of the need to both defend and expand slavery in the antebellum era required control of the diplomatic and military arms of the federal government.

To illustrate the case that elite Southerners believed in a global vision of their slave society, This Vast Southern Empire begins by examining their attitudes towards abolitionism. Karp argues that Southerners did not locate emancipatory threats solely in the North but rather throughout the globe. Obviously, the main global abolitionist antagonist was the British Empire. Slaveholders took seriously the British government's belief in the total abolition of global slavery. Universal abolition, though, gave elite Southerners natural international allies in territories that still practiced slavery, such as Brazil and Cuba. In order to defend slavery from British threats, then, it was necessary to steer the direction of American foreign and military interests both to protect US slaveholders abroad, but also the bondage system globally. If Britain was the great abolitionist power then the United States would be, in the minds of slave-owners, the great defender of the institution. Indeed, much of what This Vast Southern Empire deals with are the frenzied imaginations of elite Southerners who saw British abolitionist threats to their slaves everywhere they looked.

Karp then moves onto familiar territory in studies of slaveholding foreign policy: expansionism. However, the book explores this topic in a particularly novel way, by examining Southern naval interests. Slaveholding support for military proliferation is a theme that Karp returns to throughout the book. Southerners required a strong military to defend from external threats to their human property. Beginning in the early 1840s, the focus of this naval discussion is John Tyler's Secretary of the Navy, and later Secretary of State, Abel P. Upshur. Karp cites fear of British influence and Upshur's belief that the US Navy needed enlargement so it could compete with European rivals to explain certain American foreign policy moves in the 1840s. American jockeying with the British fleet in the Pacific, for instance, is all part of the grand battle over slavery. Thomas ap Catesby Jones' seizure of Monterey in the mistaken belief of war between Mexico and the United States in 1842, is for Karp part of a plan to deny Britain a foothold on the west coast of North America. Jones and Upshur feared that Britain had made a secret alliance with Mexico, taking California with legions of free 'colored battalions', which would serve as a beacon of slave insurrection and escape. There is no suggestion that Jones believed he seized California for slavery, but more to deny Britain the prize, and fend off the horrors of armed black troops on the North American continent. In This Vast Southern Empire, expansion is about defence rather than opening new territory to slavery.

Texas' annexation is also presented as part of this story of American expansion in the cause of defending slavery. Karp argues that Southern interests wanted to defend Texas as a slaveholding society rather than annex it. However, when it looked to slave-owning Southerners as if the British government had designs on the territory, annexation became, in their minds, the most effective means of defence. Karp adds that annexation had the double bonus of assuring US dominance in the cotton trade, thus protecting the country from British interference given the importance of commerce in the crop. British policymakers were unlikely to threaten American slavery if it meant a complete cessation of the trade in cotton between the South and Northern England. Again, This Vast Southern Empire casts American foreign policy makers as reactive to British threats and engaged in a defence of slavery rather than as spoilers for more territory.

Karp's argument about expansionism is particularly effective in its framing. The book concentrates on elite actors like Upshur, John C. Calhoun, and others in the Tyler administration, and their communication with fellow elite slaveholders. Given the high number of Southerners in the military as well as in civilian roles such as Secretary of War and the Navy in the antebellum era, the case that in martial foreign policy events like the annexation of Texas these Southerners acted to defend their interests and out of fear of global abolition is convincing. The connection between slaveholding anxiety at the top of government and military action is for the most part clear. Karp is also able to draw out larger themes from the communication of key figures. Political rhetoric around slavery and foreign policy is used to illustrate the argument about expansion. For the most part This Vast Southern Empire contains an effective narrative about how various elite Southerners communicated their ideas, and how fears and conceptions of global politics could translate 
into policy. There are, though, a few points where the connection between a global defence of slavery and individual action gets a bit tenuous. In the discussion of communication between Upshur and Thomas ap Catesby Jones for instance, it is the fact that both men are slaveholders that makes the seizure of Monterey about slavery. There is, however, no overt statement (to employ a cliché, no smoking gun) from Jones that he believed himself to be defending the territory explicitly from British abolitionism., though to defend the assertion made by the book, he seemed sure the outwardly pro-slavery Tyler administration would back up his action. That small quibble aside it is easy to see how this worldview of bondage and anxiety could infect the elite military and diplomatic community of slaveholders.

Departing from expansionism, This Vast Southern Empire moves to examine efforts to defend slavery abroad. Southern interests in Brazil and Cuba, the two largest slave societies in the mid-19th-century Americas, were directed towards defending the institution of slavery from a worldwide cabal of abolitionists. Both nations were, for slaveholders and the elite Southern-dominated US diplomatic corps, sites of political intrigue and rhetorical tools. For instance, Southerners fretted over calls for manumission in Cuba, particularly when one Spanish governor planned to emancipate all slaves illegally imported from Africa, about one third of the population. Anxiety surrounding Cuban manumission was enough to hold back elite Southern support for filibustering expeditions to the island, as they feared that repeated failures would provoke emancipation. Trade between Brazil and the United States offered possible future opportunities for slaveholders to export surplus slaves and remind Northerners of their economic reliance on trade with the 'slave power' to the south. Like American expansion, defending slaveholding in the Americas was another element to this global protection of bondage.

This section on defending slavery abroad could have used some elaboration though. Much of Karp's discussion on Cuba is about communication between the United States and the island. Given Cuba's status as a Spanish colony, it seems self-evident that this story must extend beyond the limits of the Americas. Southern links to Spain are not discussed in any detail, but one imagines that for slavery to have survived so long in Cuba there must have been some in the metropole politically committed to the institution, or at the very least profiting from it. If global protection of slavery was so key for Southern slaveholders, then the lack of any record of communication with Spain is surprising. The lack of engagement with proslavery elements in Europe extends outside of Iberia. Slavery was still legal in the Dutch Empire in this period, notably in Suriname, yet connections between the South and the Netherlands are not discussed. Karp mentions Southern fantasies that France would re-conquer Haiti and subjugate its black population once again. Although, as noted above, the imagination of Southerners could be fantastical, believers in this scheme must have had some connection to France to justify this idea. France, of course, only freed its slave population in 1848, towards the end of James K. Polk's presidency, that is to say within the scope of the book. Further engagement with ideas about slavery in Europe would help to illuminate the Southern worldview even further.

The basis of slaveholders' motivation for believing in a global vision of slavery in This Vast Southern Empire is the way that bondage fitted with the modern capitalist economy. For Karp's slaveholders, bondage was not an out-dated labour system but rather a necessary tool to develop certain regions of the world. As numerous historians have shown, the importance of American cotton to the economy of Northern England was not lost on Southerners, but Karp explores larger ideas around slavery's use in the global economy. Southerners took the importation of Asian labourers to the British Caribbean as a sign that certain areas of the globe could not be exploited without bonded workers. Indeed, slave-owners could look across the globe at other examples of unfree labour to make the claim that their system was not novel but in fact consistent with the way much of the labour market operated. Slaveholders were even drawn to Africa as the next great frontier that required unfree labour. For slaveholders, then, the institution was not on the decline, not flagging in the face of global opposition, but a tool the modern world would come to appreciate in time.

These connected visions of slaveholders, on the one hand seeing the global nature of slavery and the need to defend the institution across the world, and on the other the promising future of slavery, leads for Karp to the final point of This Vast Southern Empire. To assure a global defence of slavery, Southerners had to control 
the military and diplomatic apparatuses of the federal government. The United States' army and navy had to be strong enough to defend from abolitionist foreign threats while the diplomatic corps needed to be well disposed enough to slavery to protect slaveholders abroad, and Southern interests in other slave societies. Slaveholders were only advocates of small government and states' rights when it suited their interests. When amenable Democrats were in power, slaveholders wanted a stronger army and to expand military spending, but when the more hostile Republicans took over following the 1860 election, Southerners reversed their argument. Adoption of political positions about states' rights was situational and subservient to the greater Southern vision of global slavery. Karp's coup de grace against the myth of Southern belief in small government is the creation of the Confederacy. Creatures of the federal government like Jefferson Davis and Alexander Stephens dominated the Confederacy's leadership, and its constitution gave sweeping power to the executive. Confederates were not creating a states' rights paradise, but rather another strong executive to make up for the one they had just lost.

On the whole, the argument of This Vast Southern Empire fits together well, particularly the case that future leaders of the Confederacy were advocates for the expansion of the federal government when it suited their purposes. There are a few minor issues with where focus is placed, but overall This Vast Southern Empire makes an effective case by combining a number of factors to make up a coherent slaveholding worldview. Karp is able to show particularly well the way that Southern ideas about the globe, both in terms of a militaristic foreign policy but also wider- ranging economic ideas, influenced domestic politics. The book is a good example of how to combine a study of American ideas about world power and the global economy with a study of federal policy, and helps to better illuminate Southern thinking on slavery and government.

\section{Notes}

1. Sven Beckert, Empire of Cotton: A Global History. (New York, NY, 2014). Back to (1)

2. E. J. Hobsbawm, The Age of Capital, 1848-1875, History of Civilisation (London, 1975).Back to (2)

The author is happy to accept this review and does not wish to comment further.

\section{Other reviews:}

Early Americanists

https://earlyamericanists.com/2016/09/14/review-matthew-karp-this-vast-southern-empire/ [2]

New York Journal of Books

http://www.nyjournalofbooks.com/book-review/southern-empire [3]

Foreign Affairs

https://www.foreignaffairs.com/reviews/capsule-review/2016-12-08/vast-southern-empire-slaveholders-

helm-american-foreign-policy [4]

Source URL:https://reviews.history.ac.uk/review/2106

\section{Links}

[1] https://reviews.history.ac.uk/item/252681 [2] https://earlyamericanists.com/2016/09/14/review-matthewkarp-this-vast-southern-empire/ [3] http://www.nyjournalofbooks.com/book-review/southern-empire [4] https://www.foreignaffairs.com/reviews/capsule-review/2016-12-08/vast-southern-empire-slaveholdershelm-american-foreign-policy 